\title{
Translating the Ant's, the Hoopoe's, and the Beast's Speeches:Arabic/English/French Concerning Chapter 27 of the Holy Qur'an
}

\author{
Abdel Rahman Adam Hamid \\ Department of English Language and Translation \\ College of Science and Arts, Qassim University (QU), Saudi Arabia
}

\begin{abstract}
This article uses an analytical descriptive approach to develop its main question: do insects, birds and animals speak? Its central aim is to point out the shortcomings that may arise from the translations of the Qur'anic Verses (Ayahs). This has a significant impact on learning foreign languages through translation, and that linguistic studies on animal's, and birds' words have to continue. However, the present study isn't based on experimental laboratory research seeking to analyze their means of communication. The author tries to suggest a reading and linguistic methods that may enhance and provide guidance for the process of the interpretation of the meanings of such Verses or Ayahs. He also attempts to facilitate their understanding when translated into English/French. The study finds out that literal translation develops shortcomings in the rendering of similar Verses, into English and, or French. Another item related to the findings is that in the translations of pronouns the author, sometimes uses parentheses to clarify the meaning. The study recommends the using of specific translation techniques and authentic Islamic books of explanations and commentary while interpreting the Qur'anic Verses. Further studies on the mentioned species' communication recommended to clarify the animal words. The study concludes that the translation methods help in the delimitation of the problems of translation of the language of insects, birds, and animals mentioned in the Holy Qur'an.
\end{abstract}

Keywords: animal language, ant's speech, birds' language, English-French translations, Qur'anic translation

Cite as: Hamid, A. R. A. (2020). Translating the Ant's, the Hoopoe's, and the Beast's Speeches:Arabic/English/French Concerning Chapter 27 of the Holy Qur'an. Arab World English Journal for Translation \& Literary Studies 4 (3) 46 -65.

DOI: http://dx.doi.org/10.24093/awejtls/vol4no3.4 


\section{Introduction}

Allah $^{\mathrm{i}}$ Almighty created the creatures according to what was revealed in the Holy Qur'an and in the other precedent authentic revealed Books, by His capability to do whatsoever He wants to do, and by His Divine Order. These creatures are human beings, animals, the worlds and what they contain. However, there are some differences between the Islamic story of the creation, and those of the other Books. There are differences in the account of the nature of Adam, the first human being, the reason and how he had expelled from heaven to the earth. His wife Eves and their eternal enemy envier, Iblis ${ }^{\mathrm{ii}}$ also ordered to descend to the planet. There are also differences between the Muslim Scholars, and those of the precedent religions concerning the origin of life: was there life before the present?

The present study tackles the speeches of insects, birds and animals or pets, ${ }^{\text {iii }}$ as mentioned in the Holy Qur'an, Surah 27. The author shall give examples extracted from the Qur'anic Surah 27. The research intends neither to draw a theory on how animals, insects and pets communicate nor stating rules and morphology of their speeches. It doesn't mean to prove that ants or birds communicate by forwarding linguistic confirmations or religious ones. If that latter is the objective of this study, the author needs only to develop it, and targeting it to people who have Islamic faith. That is why the units, and speeches analyzed in the framework of translation. For so doing, the author will cite some sentences said by an ant, a bird and the Beast of the earth mentioned in Surah 27 of the Holy Qur'an. Their speeches are governed by rules, and in some cases, as that of the ant, it is more elaborated compared to some humans.

The present study is also an attempt to analyze and understand the language of insects, birds and pets, as stated in the Holy Qur'an, and the Islamic Traditions or (Sunna) of Prophet Muhammad (Peace be upon him); (PBUH) ${ }^{\mathrm{iv}}$.

Understanding these expressions will not be in their original utterance, and forms but, as revealed in the Arabic language, the Holy Qur'an. Their description and analysis in the present study will be through examples in English and French. The aim is to interpret the expressions of these species. Namely, the study will present the Verses in which the ants, Hoopoe and the Beast talk in the Holy Qur'an.

The author could have borrowed these readings from English sources like that of Y. Ali or any recent one, or, from the translations done in French by someone like Hamidullah M. or Kechrid S., for example. However, the author will translate himself, these units, and Verses then will focus on the shortcomings, and translation processes they reveal.

As in linguistics, language is the ability of humans, with the aid of tools, devices, rules and units used in the communication, spoken or written. The author adds some criteria known by all linguists, that permit to distinguish a language from a 'non-language.'

Arab World English Journal for Translation \& Literary Studies 


\subsection{Human Language Criteria}

\subsubsection{The Four Criteria that Describe a Language are}

a) Words, the vocabulary or what some linguists such as Bloomfield, in the United States of America (USA), in their analysis, call 'morphemes' or in France, referred to by Martinet (1960), as (Morphème);

b) Syntax and Grammar (Rules).

c) Phonology, phonetics, phonemics and,

d) Style.

As the purpose of a language is to permit the communication between humans, mainly, social groups, those who speak languages should have the ability to acquire the four criteria mentioned here-above. Moreover, words are learned from mothers, native speakers, and a specific community (mother tongue) or taught at school or within other alien or foreign cities. Modern theories of linguistics tell us that one may learn the rules to combine words and make sentences according to specific processes still, the ability to form sentences, is unlimited: to be limited by either the stopping of producing sentences intentionally or the death.

We shall see from now on that sounds made by animals or birds, or other species, discussed in the Holy Writings are also types of words: they fulfill the same role as the human languages mentioned previously.

\section{Statement of the Problem}

There are a hundred translations of the Holy Qur'an in many languages of the world. The fact that humans speak constitutes no problem to linguists. However, some researches were conducted on the chimpanzee's, the apes', the birds', the bees' words. Some researchers continue studies on this question. Others think that the expressions of these pets, and insects are simple and need not be focused on or treated for the simple reason that it will be difficult to understand. However, some revealed Books describe these words, mainly the Holy Qur'an as sophisticated and as developed forms of communications. These researchers who continue studies on birds songs and animal words make observations regarding the nature, reproduction and the investigation of these words, linguistically, in laboratories. Yet, to think that other species have words is a matter of belief and not a question of scientific analysis. That is why the present analysis, given after this, may reveal some exciting responses regarding the translation of the meanings of the Qur'anic Verses given in the English, and the French languages.

\section{Previous Studies}

Among the studies on the translations of the Holy Qur'an into the English language one counts the followings: 
a) Al-Hilali., M. T. \& Khan M. M. (1404H). Translation of the Meanings of the Noble Qur'an in the English Language.

b) ALI. Yusuf. (1983). The Holy Qur'an, Text, Translation and Comments.

c) Qaribullah, Hasan \& Ahmad, Darwish. (2001). The Holy Koran.

In the French language there are famous works such as those of the followings:

1. Hamidullah M. (1986). Le Saint Coran. Traduction Totale et Notes. 12e ed. Muassassat Arrissalah. Beyrouth.

2. Kechrid Salah Ed-dine, Al-Qur'an al-Karim, traduction et notes, 3ème éd. Dar Al-Gharb Al-Islami, 1981.

3. Hamza Boubakeur (1989). Le Coran. ed. Enag, Alger.

4. Masson Denise. (1967) le Coran 1 et 2, ed. Gallimard.

5. Le Noble Coran et la traduction en langue française de ses sens. (1427H). Complexe du Roi Fahd pour l'impression du Noble Coran. Médine. www.qurancomplex.org.

6. Adam Hamid A. (The Author). Recueil des commentaires du Saint Coran. (1990), and (2005)

\section{Study Questions}

1. What are the problems that encounter the translator when he/she translates insects', birds' and animals' words extracted from the Holy Qur'an?

2. How can the rendering of the insects', birds' and animals' expressions revealed in the Holy Qur'an be understood and not considered difficult?

3. What are the benefits of the translation of insects', birds' and animals' words when it analyzed in the framework of linguistics and translation?

4. Can we call language the means of communication of these species?

\section{Study Hypotheses:}

1. Some problems encounter the linguist-translator when he/she converts insects', birds' and animals' words extracted from the Holy Qur'an? 
2. Are there difficulties while rendering the Texts in the insects', birds' and animals' talk revealed in the Holy Qur'an or in the Prophet's traditions (PBUH)?

3. There are benefits of the translation of insects', birds' and animals' Words?

\section{Background}

Animals' communication mentioned in many religions and cultures. The Hebrew Bible or the Books of Jewish, the Old Testament, the New Testament and the Holy Qur'an evoke these phenomena.

The Bible affirms that two animals talked: the serpent and the donkey or ass of Balaam.

Regarding the saying of the donkey: the following text appears in the biblical sources:

"Balaam then sets out in the morning with the princes of Moab. God becomes angry that he went, and sends the Angel; of the Lord (Numbers 22:22) to prevent him. At first, the angel is seen only by the donkey Balaam is riding, which tries to avoid the Angel. After Balaam starts punishing the donkey for refusing to move, it is miraculously given the power to speak to Balaam (Numbers 22:28) and it complains about Balaam's treatment. ${ }^{\prime \prime}$

The Holy Qur'an, on which the present translation study based, exposes this aspect in many Chapters (Surahs) ${ }^{\text {vi }}$.

Regarding the international culture and linguistics, the words of the animal were tackled by some linguists such as $\mathrm{N}$. Chomsky. He conducted researches on generative grammar in the 1950s that inspired, and motivated some researchers to think, and observe birds' songs considered as languages.

Considering pets, some studies on this subject were made by some linguists with an important question: do pets or companion animals, and birds that talk do this with cognitive understanding or not? We have some answers to this question in some studies that proved this. The grey parrots of Congo in Africa can talk when they were one-year-old. (See and Deter, Dianalee (2000) and Bono, Lisa. 2014). Likewise, the Casco parrot, similar to the African grey one, learns and repeats words and even sentences in the language of humans. The pirate's parrot that could talk existed in real stories and novels. Bandit and pirates who attacked ships across the seas were examples that revealed the ability of these birds to speak. Some of these stories were imaginary, they reflected the reality and facts that some parrots could reproduce human language.

Eagles and dogs trained to participate in hunting rabbits or smaller animals and birds. The master of the eagle in some Arabic countries, in games, order the eagle to chaise a hunted Beast, catch it and bring it bag or help his/her master to come and take it. These eagles respond to specific, even though limited words. 
In Sudan, in Gezira State, dongs trained to participate in hunting rabbits and gazelles. They respond to the order of their master and chaise, for instance, a rabbit. The only difference is that dogs don't fly like eagles, but they are animal companion and friends of humans that understand, to some extent the human talk given in the form of orders. As well, the animals of the circus, fulfill hard responsibilities: jumping here, standing there according to the mandate given by their masters. The essential issue that concerns us here is their obedience to accomplish their tasks. This explains that not only chimpanzee or police dogs are the only to understand specific words uttered by the master to participate in the game.

In Nicaragua, some linguists isolated some birds somewhere. These birds developed songs, in two generations that were similar to the songs of the wild. The researchers came out to the conclusion, not proved, but remarked that the songs, which we call language in this research, run in the minds or blood of the birds.

To conclude this subchapter, cite Kentaro Abe, Hisataka Fujimoto \& Others wrote an article entitled: 'The Mechanisms for Motor Programming of vocalizations in songbirds.' They stated similar remarks on birds' songs.

Insects like ants and bees have their means of communication. (See Riley, J.R., U. Greggers, A.D. Smith, D.R. Reynolds \& R. Menzel, (2005b), Gorman J., (2016) and Shugart J., (2016).

The Holy Qur'an speaks of bees in Surah named 'The Bees', No. (16): (Your Lord inspired the bee, saying:

\section{8. "Build your homes in the mountain, in the trees and in what they construct."}

69. Eat every kind of fruit and follow the ways of your Lord, made smooth (for you). From its belly comes out a drink of many hues in which there is medicine for the people. Surely, in this there are signs for the people who reflect."

These ways, which followed after a dance, were discovered by German biologists and other scholars: Riley J.R., U. Greggers, and others. The dancer bee sends a code to the others, informing them of the place of the food. This is the conclusion, according to Karl von Frisch, who won the Nobel Prize for discovering this language manifested through the dance.

Based on personal experiences, we saw birds in the forests of the state of Kordofan in Sudan, disturbed, and producing sounds that make the other birds fly away. The mother or father stirred fly around its nest, continuing the same movements and sounds. When one looked nearer, to see why these birds did that, sometimes a snake was trying to swallow the eggs of these birds. The remark drawn out of such scenes and incidents was that: the songs or words send to the other birds were significant: there was danger. Likewise, when the mother or father returns to the nest, the small birds begin to present sounds that are different from those presented in the time of 
danger or quarrel and fight between the chicks themselves or against another bird that would like to steal some items of the nest.

In modern cartoons or those of mixed characters, since the 1980s and in the books for children, animals communicate. Tom and Jerry cartoon or animated movies are pleasant instances. In the Red Indians and the early African cultures, for example, there were sounds to imitate the words of birds either to communicate by camouflage in the presence of danger, to pass information to their brothers when strangers entered into their territories. Sometimes to cheat the birds to hunt them. These voices and cries done for other purposes. Thus, they indicate that birds have languages.

Among Westerners, there is a great deal of difference. Some of them think that animals cannot think about the future. If you tried to beat a dog and it ran away and met other dogs, it could not tell them not to go in that direction as there was someone throwing stones at dogs, etc.

Recent studies in Australia, conducted on Cockatoos, cite that ex-captive birds that rejoined the flock passed personal address to the other birds through cultural transmission. The speech transmitted is described to be passed on as linguistic-cultural communication: expression transferred from ex-captive birds onto others. (Price 2011).

\section{Material}

The primary subject material of the present study is Verses 16-28 of Chapter 27 of the Holy Qur'an and Verse 82 of the same Chapter (Surah). In these Verses, Allah, tells us what the ant, the Hoopoe, and the Beast says.

The translation conducted in the present study is for these Qur'anic Verses, mentioned

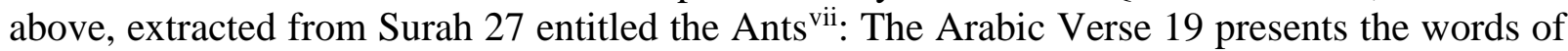
the ant when Prophet Salomon (PBUH) passed through their valley. The chef ant, scared, and fearing to be crashed, called upon the other ants to go into their houses. In Verse 22 of the same Surah, the Hoopoe speaks to King Salomon, but in another area. The Hoopoe, according to the Verses, was used to locate the areas where there was underground water. It snaked away and flew to ancient Yemen where Balgis the Queen of Saba' (Sheba C 965-631 before the common era (BCE) was ruling her people. The Hoopoe, follower of Prophet Solomon (PBUH) and King of Jerusalem, found a Hoopoe female and fell in love with her. At the same time, it saw that, the queen and her people worshipped the sun and not Allah the Creator of the worlds.

\section{Methodology}

This study aims to determine the utility of the descriptive analytical method used to prove the service of translating the words of the ant, the Hoopoe, and the Beast mentioned here-above. It is used to answer the research questions mentioned above and develop some points to facilitate the readings set out hereunder. The purpose is to point out to what extent the translation from 
the Arabic language into the English and French languages be conformed to the process of interpretation.(See Adam Hamid A. (2010).

The methodology used in this study seeks to determine the compatibility of the process used herein to the needs of the translator. It discusses the flexibility and efficiency of these processes in the Qur'anic translation into English/French. Otherwise, the study will determine the shortcomings that yield of the use of such methods. The steps to develop the discussion of the present method are composed of the following points:

\subsection{Translation of Meaning: Contextual Meaning Translation}

It means that the author sees the meaning conveyed by the words, phrases, sentences, and units in the specific context of the translated unit.

This method proceeds by looking for suitable equivalences to use in the translation regarding any document. To apply it, the translator should be aware of its use in the specific context, and purposes of the SL.

The author uses it, herein, to proceed by the search of the closest meaning, respecting the rules of grammar of the TL, the style and the order and structures of the words. For so doing, sometimes, it is necessary to omit conjunctions and particles used in one language, still, their use in the same order in a target language will be literal and inadequate.

E.g., Verse 17, mentioned here below, begins with the particle (و), which indicates the addition of the phrase, a link between two units or items, etc. In English, it is, sometimes, useless to use the equivalent 'and,' 'et,' in French, at the beginning of a sentence or, in our case, Verse 17. So, the mentioned Verse begins in Arabic as follows: (...

But in English and French, there will be an omission of the (واو =و). Thus, the translation of the concerned Verse in English is as follows:

17. "There, were gathered before Solomon his army of jinn, humans and birds; gathered and dispersed."

It could be translated as follows: 17 "Before Solomon, there were gathered, his army...

The author prefers the first translation.

In French, the Verse (Ayah) commences with a passive voice. Separated by an interceptive phrase that separates the subject from the predicate, usually by using commas.

17. "Les armées de Salomon, (composées de Djinns, d'hommes et d'oiseaux), furent rassemblées et placées en rangs. 
In case someone translates the Verse as follows: (Gathered before Solomon...)(Author, 2005)

There will be a lousy or an unfortunate omission, literal translation, where the units of the source language (SL) translated by similar ones in number with failure of the real equivalences necessitated by the context, the rules grammar, and the stylistics. To conclude this section, the reader understands that, not only in the Holy Qur'an, but also in all documents, the method of the translation according to the sense, is at the core of the process of conversion. However, in case of failure due to the stylistic rules of the TL, the process should be taken with high care: is the failure concerns the purposes or the particles, punctuation, conjunctions and the like, the use of which is not preferred by the TL linguistic and cultural system? In case the failure causes shortcomings in the sense of the units of SL, it should be rejected. The translator is always loyal, accurate, and faithful to the SL and the TL.

\subsection{Literal Translation}

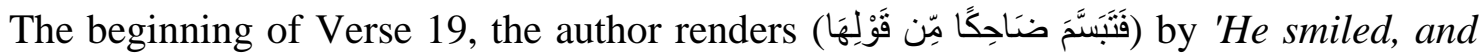
laughed at its speech' this is a literal or word for word translation. It is justified by the explanations: did Solomon (PUBH) laughed? Prophets were simple persons. Was he amused? The books of interpretations of such Holy Writings say: - No, not in the sense of being happy to see the ants worried and scared to death. So, the author has chosen the literal translation. The reader may refer to the interpretations and commentary received from the former or the contemporary explanation.

\subsection{Paraphrasing}

The author calls paraphrasing the words put between parentheses to clarify the meaning of the Arabic words once conveyed into English or French. In ordinary literary translation this method is called, by translators as 'over translation.' E.g.: The Qur'anic terms (الَْضْلُْ الْمَبْبينُ) translated by the following terms two of them are synonyms and put in brackets: 'Clear plenteousness (Reward or bounty).'

\subsection{Explanations}

It is the method of elucidation and clarification of a term or a unit used in the Qur'anic Verse. When the translation is elucidated by the author, according to the Arabic language and his description and justification of the use of a term, the author calls it 'explanation.' It is not to be confused with the meaning of the explication themes when extracted from the books of explanation: a method of 'interpretation', 'commentary' or 'explications.' The author preferred the term 'interpretation' to refer to these latter themes. The explanation is made by the author; the other types of explications, extracted from the Islamic books, called of commentaries or explications or interpretations.

Arab World English Journal for Translation \& Literary Studies 


\subsection{Interpretation}

Interpretation is the clarification of the linguistic Qur'anic unit extracted from the explanation given by exegesis or the reported Holy Hadith or their clarification and enlightenment permitted by the context and the authentic published items. E.g.,

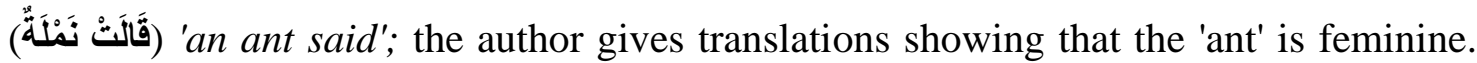
All ants called as if they are females. How to decide when the issue concerns a Holy Book, which means there should be no chance for forging or falsifying of the meanings of the real context.

The answer is given by the exegesis: the ant was female.

The same report and critical opinion apply to the French translation.

\subsection{Footnote}

A footnote is a comment put at the end of the study or bottom of the page for further information about the term or ideas referred to explain them. Thus, the author avoids alteration, forgery, or falsifications of the original text. He/she uses footnotes so as not to change the original copy. (Author 1990-1993)

\section{Assumptions and Analysis}

Hereunder, the author will analyze the Verses extracted from Chapter 27 Surah the 'Ants' of the Holy Qur'an, and will forward some assumptions.

\subsection{Legal Opinion of Islamic Scholars on Languages}

All Muslim scholars such as the Imams: Abu Hanifa, Malik, Chafiay, Ahmed who were of the $8^{\text {th }}$ century CE, on whom opinions and books based the majority of the opinions of jurisprudence as well as those of the recent times, agree that the letters of the Alphabet are ancient but not created. So any human language is a miracle of God. It is not conventional. Thus, the same opinion may be said about the other species' words such as ants, by comparison, as they are gifts given to them: a sign or Miracle. The mentioned statement is a religious legal opinion. In the linguistic studies, the matter may take other dimensions: comparing birds' songs to music etc. However, the author will analyze the words of the ant, the Hoopoe, and the Beast within the scope of the methods of translation.

\subsection{Insects' and Birds' Words}

The words of the insects, the songs of birds, all animals', and pets' phrases are from Allah (Almighty). From this point of view, the author shall deal with the expressions of animals in the Holy Qur'an. 


\subsection{Animal Words and the Islamic Opinion on Animals, Insects and Birds}

The opinion of Muslim scholars is that animals are communities just like humans in their organization, in consequences, they have words.

\section{Sources and References of Analysis}

Our source will be the Holy Qur'an. Precisely, the words of the ant. The expression of the Hoopoe with Prophet Solomon (PBUH), and the words of the Beast with the humans.

\subsubsection{The Speech of the Ant}

The examples for that are the words pronounced by the ant, those of the Hoopoe, and the Beast; in Chapter 27 entitled 'The Ants.' Allah says:

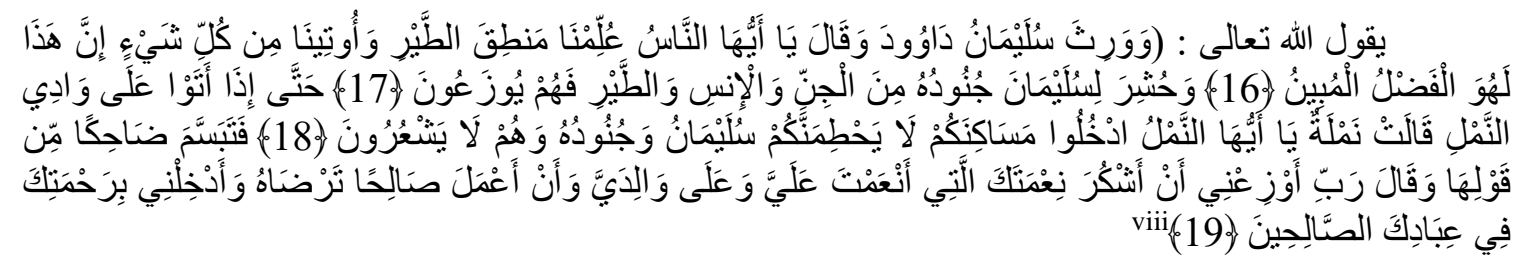

The author gives the translation of the meaning for these Verses as follows:

16. And Solomon inherited David. He said: "O, my people, we have been taught the words of birds and we have been given everything. Surely, this is the clear plenteousness (Reward or bounty)."

17. There were gathered before Solomon his soldier of Jinn, human, and birds and all dispersed,

18. And when they came to the valley of the ants, an ant said, "O ants! Enter into your dwellings lest Solomon and his soldiers should, unknowingly crush you."

19. He (Solomon) smiled, and laughed at its speech, and said: "My Lord, inspire me to be thankful for Your favors which You have bestowed upon me and upon my parents and that I may do good works that will please You. And admit me by Your Mercy into Your righteous worshippers. ${ }^{\mathrm{ix}}$

In Verse 16, cited here-above, the words "the language of birds" means their words or speech. There is a shortcoming in translating it due to the problem of synonymy. The author of this paper preferred the term 'words' as equivalent to the Qur'anic composed term 'منطِقَ الطُّنِِْ because the term 'words' expresses a general idea. It denotes the entire units of a language: the whole components; the words, style, grammar and phonology. A word for word translation may result in an English word such as 'logic' which will be false and misleading. The meaning of the term 'logic,' means the branch of philosophy that a person may give to refute the evidence of 
his/her adversary. Or, maybe rendered by 'utterance' from ' نطق /nutq/, which is near to the

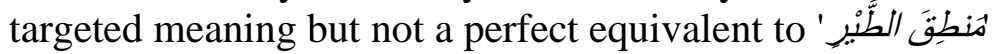

Also, Verse 16, translated by the author giving the biblical names of Prophet 'Solomon' and 'David' (peace be upon them both): the translations of these names, done according to the process of rendering the famous names as those of Prophets. Otherwise, if the names are of ordinary people, the translation is done, for example, with differences in spelling or transcription, in the following method: the transcription of the name 'Solomon' may be 'Suleiman' and 'David' as follows 'Dawud.' At the head of the Verse, the author added 'and' to be accurate in translating the Arabic device (و) of the Arabic ' آية ' 'Aya.'

In the same Verse 16, King and Prophet Solomon (PBUH) declared that he knew the language or words of birds. According to the faith of Muslims he could speak with all kinds of animals, birds, and demons, etc.

Verse 17, cited here-above comes in the Arabic language in the passive voice, which means that Who gathered the army was Allah. Therefore, it may be rendered in English as follows: 'Allah Gathered ...' or 'We gathered ...' It is evident that the pronoun 'We,' refers to 'Allah' or 'God.'

In French, the author translated the Qur'anic Verse as follows:

16. "Salomon hérita de David et il dit: "O vous les hommes! On nous a appris le langage des oiseaux. Nous avons été comblés de tous les biens : voilà, vraiment, une grâce manifeste."

17. "Les armées de Salomon, composées de Djinns, d'hommes et d'oiseaux furent rassemblées et placées en rangs.

18. "Quand elles arrivèrent à la vallée des fourmis, une fourmi dit : "O vous les fourmis ! Entrez dans vos demeures de peur que Salomon et son armée ne vous écrasent sans s'en apercevoir.

19. Salomon sourit à cette parole et dit : "Seigneur! permets-moi de te remercier pour les bienfaits dont Tu m'as comblé, ainsi que mes parents, et d'accomplir le bien que Tu agrées. Fais-moi entrer, par Ta miséricorde, parmi Tes saints serviteurs. ${ }^{x}$

According to the commentary of the Qur'an, the ant was scared and frightened that the horses of King and Prophet Salomon (PUBH) may crush them.

\subsubsection{The Speech of the Hoopoe}

We know well that these insects, animals and birds can speak. Among that is what Allah (Almighty) said about Prophet Solomon (PBUH), and the ant on the one side, and the Hoopoe on the other side. Regards the words of the Hoopoes, the author cites the following Verses in 
Arabic and then will translate them into English and French, followed by analysis to see the shortcomings or accuracy that they reveal; Allah says in the Holy Qur'an:

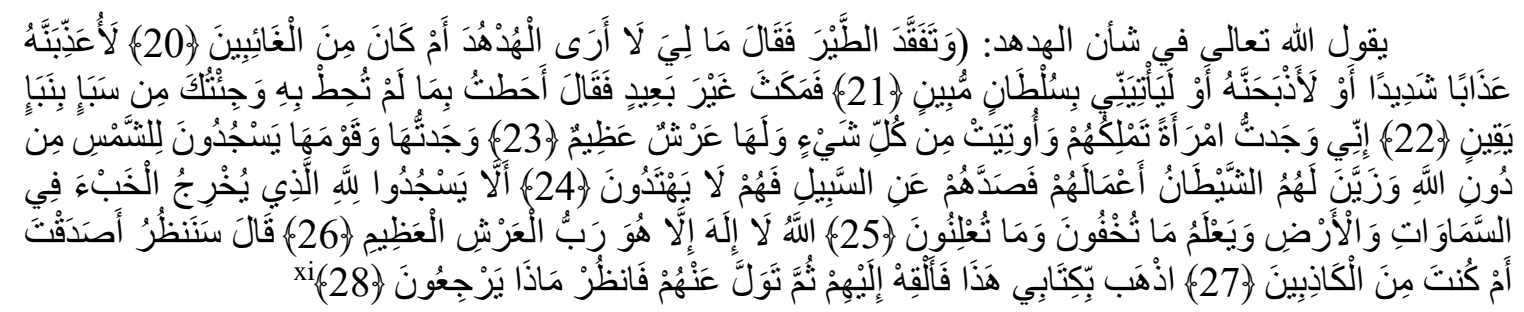

The meaning of these Verses translated as follows:

20- "He reviewed the birds and said, "Why do I not see the Hoopoe, or is he among those absents?

21. I will, surely, punish him with a severe punishment or slaughter him unless he brings me good reason."

22. But the Hoopoe stayed not long: and said, "I know what you don't know; I came to you from Sheba with certain news.

23. There, Indeed, I found a woman ruling over them. She has been given everything and she has a magnificent throne.

24. I found her and her people prostrating to the sun instead of Allah, and Satan has made their deeds seem pleasing to them and averted them from the Path, so they are not guided.

25. So do they not prostrate themselves to Allah, Who brings forth all that is hidden in the heavens and the earth and knows what you conceal and what you reveal.

Which means in French (Qui signifie en français) :

20. Il (Salomon) passa en revue les oiseaux, puis il dit : "Pourquoi n'ai-je pas vu la huppe ? Serait-elle absente?"

21. Je la châtierai d'un cruel châtiment ou bien je l'égorgerai, à moins qu'elle ne me présente une bonne excuse."

22. Celle-ci revint peu de temps après et elle dit: "Je connais quelque chose que tu ne connais pas! Je t'apporte une nouvelle certaine des Saba.

23. J'y ai trouvé une femme : elle règne sur eux, elle est comblée de tous les biens, et elle possède un trône immense. "xii

Arab World English Journal for Translation \& Literary Studies 
24. Je l'ai trouvé, elle et son peuple, se prosternant devant le soleil et non pas devant Dieu. Le Démon a embelli leurs actions à leurs propres yeux; il les a écartés du droit chemin ; ils ne sont pas dirigés."

25. "Pourquoi ne se prosternent-ils pas devant Allah qui met au grand jour ce qui est caché dans les cieux et sur la terre, qui sait ce que vous dissimulez et ce que vous divulguez ?"

26. "Dieu! Il n'y a pas de Dieu que lui !... Il est le Seigneur du Trône immense !"

27. "Salomon dit : "Nous allons voir si tu dis la vérité ou si tu mens :"

28. "Pars avec ma lettre que voici ; lance-la aux Saba, puis, tiens-toi à l'écart et attends leur réponse."

The author of this article draws the attention of the reader to the fact that the 'Hoopoe' is female in French. The word 'ant' in Arabic denotes a feminine.

The author comments:

"Ibn Kathir rapporte qu'Ibn Abbas (Qu'Allah soit satisfait d'eux) a dit que la huppe était un ingénieur géologue qui voyait l'eau dans les couches de la terre. Elle informait, alors, Salomon qui campait là où il y avait de l'eau. Un jour la huppe manquait à l'appel et faussait compagnie, au Prophète. (Prière d'Allah sur lui), (PASL).

These clarifications in French point out the qualities of the Hoopoe. It accompanied Prophet Solomon (PBUH) to show the location of the underground water for the army of Prophet Solomon (PBUH) who wanted to kill it in case of telling lies about its absence.

In Verse 20, the author uses the parenthesis to rewrite the name of Prophet Solomon (PBUH) to clarify the meaning, at the same time in Arabic, the Qur'anic context is very apparent: Needless to repeat the title of Prophet Solomon (PBUH).

In Verse 22, the French language renders the Qur'anic terms by: 'bonne excuse.' The same words translated into English as a 'good reason.' Some translators, like those of the Complex for the printing of the Holy Qur'an, use the terms 'clear reasons.'

We remark that the pronouns mentioned in the Qur'anic Verse 22 are to be replaced by the entity they refer to, e.g., King Solomon (PBUH), the Hoopoe, the ant, etc.

\subsubsection{The Beast of the Earth}

Unlike the Western linguists, most of whom say that animals like chimpanzees, bears, monkeys, and dogs are intelligent animals, may learn the language of signs. Still, they do not talk, for example, in the present and the past tenses. Some forward the proof as that if a child throws a stone and hits a dog and the dog runs and meets another dog going towards the child 
who has thrown the stone at it, it will not tell the second dog to go away because there was a child throwing stones at dogs. Therefore, someone may disagree with us regarding the stories of ants, and animals that communicate. But it is proved as we have seen, here-above in the literature discussion, by Noble prize biologist, Karl Von Frisch, and others, on many fields: on animals, birds and insects as shown herein-above in the review.

There are many Hadiths reported on the speech of animals mentioned in the Holy Sunna. Moreover, in the explication of the Holy Qur'an: The she-camel of Prophet Salih (PBUH) had spoken. And, according to the Holy Qur'an, it is the animal that shall address people at the end of time telling everybody if he/she is wretched, or blessed:

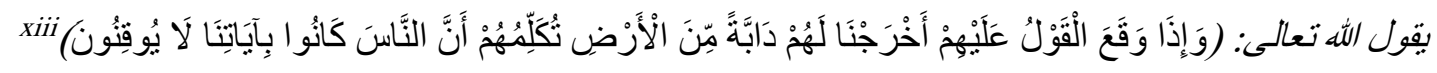

The translation of the meaning of the previous Verse may be as follows: Allah says:

82- "And when the word falls on them, We will bring out for them a Beast from the earth to speak to them, saying that the people believed not in Our Verses (Ayas)."

Which may be translated in French by:

82- "Lorsque la Parole tombera sur eux, Nous ferons sortir, pour eux, de terre une bête qui proclamera que les hommes ne croyaient pas à Nos Signes."

Here the word 'word' means the Decree that will be pronounced by Allah Almighty. The Verse may refer to the Verses of the Holy Qur'an as some signs to the people or the miracles and signs in the universe, giving signals to the Existence of Allah.

\section{Summary, Findings, Solutions and Recommendations:}

To say, we as humans can understand the words of insects, birds or pets is a pretension. However, the Prophets (Peace be upon them) did. For this reason, translating their words from Sacred or Holy Writings is very difficult. Some translators may avoid tackling the matter. The literature report, the assumptions, and analysis show that there are different approaches to birds' songs, ants', animal expressions, and that of humans.

\subsection{Findings}

a. There are shortcomings in translating of pronouns from the Arabic language into the two European languages, subject of the study. The author was obliged to use parentheses or explicative additions to clarify the meaning.

b. For the believers of the revealed religions, animals, and pets have their status, right to existence and languages: with rules of grammar, lexis, phonology, and style rich in meaning and rhetoric items.

Arab World English Journal for Translation \& Literary Studies 
c. If the majority of humans speak like the ant mentioned here-above, there will be fewer linguistic problems.

d. Explications, interpretations, and footnotes are necessary and essential methods in translation of the Quranic insects and animal communication. meaning.

e. Translation is useful when based on the contextual text, and when we look for the

11.2. As the present study is based on the translation criteria and not based on linguistic and phonological scope, the language of the animals, birds and bees may be like clicks of dolphins, or songs or voices, etc.

\subsection{Proposed Solutions}

1. We have to do further researches on animal phrases in the field of linguistics.

2. It is easy to translate the words of animals found in the Holy Scriptures than to observe rules of grammar to them.

3. Bringing the animal language in the framework of the linguistic theory of translation is possible when we look for meaning.

\subsection{Recommendations,}

\section{It Would Be Better:}

1. To have new linguistic investigations should be conducted to come out to results. But inevitably, the expressions of insects, birds, and pets, treated here in the view of translation studies, maybe types other than languages expressed in words like those of the humans, despite their interpretations of the human communication from the Holy Qur'an or Writings such as the Old Testament.

2. To conduct more investigations on animal expressions, birds' songs, etc.

3. To separate studies on animals and birds and the like in different fields, they are considering each specie distinct from, the other regards their words.

4. To base and continue researches as from, where other researchers stopped.

\section{Conclusion}

The discussion about the speeches of the ants, the Hoopoe, the Beast is related to faith. A faithful believer knows that all the animals on earth speak, as said by Allah, in Aya (38) of 
Chapter (5) or as mentioned in the previous Scriptures. Also, translation methods may reveal the shortcomings or the accuracy of the Verses treated by the translator.

Surah Al- Ana'am: Allah (Al-Mighty) says:

38- (And there is no Beast on the earth or a bird that flies with its two wings except that they are communities like you. We have neglected nothing in the Book. They shall all be gathered before their Lord.) $)^{\mathrm{xiv}}$

What is remarkable is the fact that among these animals there are some can speak in a much better way, than many people:

The phrases of the ant contained some figures of speech: ten in total as mentioned in the books of the commentary of the Holy Qur'an. The author focused on the three major ones:

1. The ant referred to Prophet Solomon (PBUH) by his name, due to his famousness.

2. The ant pointed out the dwellings, where the other ants should go.

3. Knowing that they were created from silicon, the ants didn't want to refer to Prophet Solomon (PBUH) as the one who would crush them, but the horses. By speaking in this polite way, it delivers its short speech in pragmatics.

\section{About the Author:}

Dr. Abdel Rahman Adam Hamid, received his Ph.D. in Linguistics, Languages, and Discourse Analysis, from Jean-Moulin University, Lyon III, France, 1990. Former Translation Prof., and Director of the Translation \& Arabicization Unit, U. of K. Sudan. He is currently Associate Prof. at Qassim University, Saudi Arabia. His research interests include translation, interpreting, and linguistics.

\section{References}

Adam Hamid, A. (1990a). Recueil des commentaires du saint Coran, le Chemin $d u$ Paradis, $N^{\circ}$ 30. Paris : A.E.I.F.

Adam Hamid, A. (1993b). Recueil des commentaires du saint Coran, le Chemin du Paradis, $N^{\circ}$ 29. Paris : A.E.I.F.

Adam Hamid, A. (2004c). Arabic, English \& French Lexicography. Afro-Tayeb, Khartoum. ISBN 125/2004.

Adam Hamid, A. (2005d). Recueil des commentaires du Saint Coran, Rubaa Ya Sin. Khartoum. ISBN 99942-80107. 
Adam Hamid, A. (2010e). The Methodology of Research: How to Write a University Research. The Judiciary Printing House, Khartoum. 2012/135.

Adam Hamid, A. (2018f). Theories, Categories, and process of Translation. Khartoum. Salsabeel.

Adam Hamid, A. (2018g). Les perles bien Gardées, Abrégé du Recueil de l'Imam Boukhari (QDLFM). Tome 1 et 2 : Khartoum. Salsabeel. ISBN 978-9942-869-8-0

Adam Hamid, A. (2019h). Simultaneous Interpreting of the Figures of Speech: Problems and Solutions, International Journal on Studies in English Language and Literature (IJSELL). No. 7, Issue (3). January 2019, PP 1-10. ISSN 2347-3134 (Online). http://dx.doi.org/10.20431/2347-3134.0703001. https://www.arcjournals.org/internationaljournal-on-studies-in-english-language-and-literature/past-issues

Adam Hamid, A. (2020i). Sight Translating Public Services Linguistic Components English/French/Arabic A Descriptive Process with Reference to Health, Legal and Finance Fields (BHSS). No. 24 (1). July (2020.) (pp. 28-41). ISSN 2048-1268. (Online). http://www.ajournal.co.uk/HSArticles24(1).htm.

Al-Hilali, M. T. \& Khan M. M. (1404H). Translation of the Meanings of the Noble Qur'an in the English Language. www.qurancomplex.org. ISBN9960-770-15-X: Medina.

ALI, Yusuf. (1983). The Holy Qur'an, Text, Translation and Comments.

Cambridge Content Dictionary, (C) Cambridge University Press.

Bono, Lisa. (2014). 'African Grey Parrots: Myths \& Facts.' Birdchannel.com. Retrieved March 17.

Catford, J. C. (1987). A Linguistic Theory of Translation. London.

Deter, D. (2000). The African Grey Parrot Handbook. Hauppauge. New York: Barron's. ISBN 0-7641-4140-6)

Dyer, F. C. (2002). The biology of the dance language. Annu. Rev. Entomol. 47, 917-949. CAS Article PubMed PubMed Central Google Scholar.

Hamidi, M. \& Pöchhacker F. (2007). "Simultaneous consecutive interpreting: A new technique put to the test." Meta: Journal des traducteurs52(2): 276-289. 10.7202/016070ar

Gorman, J. (2016). "Do Honeybees Feel? Scientists Are Entertaining the Idea" - via NYTimes.com.

Arab World English Journal for Translation \& Literary Studies 
Hamidullah, M. (1986). Le Saint Coran. Traduction Totale et Notes. 12e ed. Muassassat Arrissalah. Beyrouth.

Hamza, Boubakeur. (1989). Le Coran. ed. Enag, Alger.

Ibn Hajar A-Asqalani. Fath Al-Bari', Charh Sahih Boukhari. (Explications du recueil de hadiths rapportés par Boukhari).

Ibn Kathir, I. (774H). Le commentataire du Coran. Beyrouth.

Kechrid, S. (1981). Al-Qur'an al-karim, traduction et notes, 3ème ed. Dar Al-Gharb Al-Islami.

Martinet, A. (1960). Éléments de linguistique générale. éd. A. Colin. Paris.

Masson, D. (1967). Le Coran 1 et 2., ed. Gallimard.

Oxford Advanced Learner's Dictionary. On the Web.

Price, H. (2011). "Birds of a feather talk together." Archived September 23, 2011, at the Wayback Machine. Australian Geographic.

Qaribullah, H. \& Ahmad, Darwish. (2001).The Holy Koran, mosque@ mosque.com. www.Allah.com. The Mosque of the Internet.

Qurtubi, M. (1988). Aajjamia' Li A hkkam Al-Qura'n (Recueil des Lois Coraniques). éd., Dar AlKutub Al-Ilmiya. Beyrouth.

Riley, J. R. \& Osborne, J. L. (2001a). In Insect Movement: Mechanisms and Consequences. Eds. Woiwode, I. P., Reynolds, D. R. \& Thomas, C. D.) 129-157 (CAB International, Wallingford, UK.

Shugart, J. (2016). "Honeybees use right antennae to tell friend from foe." Science News. Retrieved March 12.

Tarpy, D. (2016). "The Honey Bee Dance Language". NC State Extension.

Wikipedia. https://en.wikipedia.org/wiki/Balaam

Zamakhshary, A. (2004). Al-Kushaf. ed. Dar Al-Ma rifa. Beyrouth.

\section{NoteS:}

i - Allah, as known, means God = The Lord of all creatures and the Master of the worlds. His Name in the Islamic Scriptures and Writings is 'Allah.'

Arab World English Journal for Translation \& Literary Studies 
ii - Iblis = The name of 'Satan', before expelled from heaven.

iii - Pet = As this study is trilingual regarding the translated examples, it would be better to use the composed word 'companion animal' rather than pet.' Pet designate gazes that come out from the intestine. It is a taboo in some francophone African countries.

iviv - Abbreviated as follows: (PBUH).

v - Wikipedia. https://en.wikipedia.org/wiki/Balaam.

vi - Chapter $=$ Surah. 114 Chapters constitute the Qur'an. They are called Surah in Arabic.

vii - النمل /an-Naml/

viii - Surah An-Naml [27: 16-19]

ix Ibid: Qurtubi comments in his book of explications that the valley was in the region of Taif, called Acacia Valley (وادي السدر) and that the name of the ant was 'Takhiya' (طاخية). This is acceptable for the simple reason if Solomon (PBUH) heard her from so near the army would have crushed the ants before entering into their dwellings.

x - Ibid, Versets [17-19], traduit par l'auteur du present article. (Translated by the author of this paper).

xi - Surah An-Naml [27: 20-28]

xii - Cette reine est Balgis fille de Shrahil (بلقبس بنت شر احيل) reine de Saba.

xiii - Surah An-Naml [27:82].

xiv - Surah al-An ${ }^{\mathrm{c}}$ am [6:38]. 